\title{
Interference of different storage temperatures in the dynamics of probiotic Bifidobacterium spp. and Streptococcus thermophilus starter cultures in fermented milk
}

\author{
Interferência de diferentes temperaturas de armazenamento na dinâmica \\ de Bifidobacterium spp. probióticas e cultura starter Streptococcus \\ thermophilus em leite fermentado
}

\author{
Rosângela Freitas', Rodrigo Otávio Miranda², Gabriel G. Netto', Luís Augusto Nero*, \\ Antônio Fernandes de Carvalho ${ }^{1 *}$
}

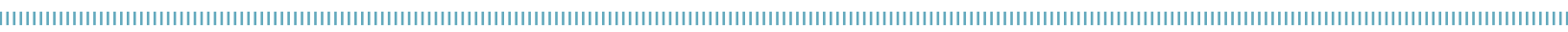

\begin{abstract}
The variations of temperature during the cold chain can impair the quality of live foods, such as fermented milks. Probiotic bacteria are commonly added to food to provide the consumer with beneficial effects. Nevertheless, the concentration of probiotic in the end products should be elevated to ensure functionality. The aim of this study was to evaluate the viability of probiotic strains of bifidobacteria and starter strain of Streptococcus thermophilus in fermented milks at storage temperatures of 4 and $10^{\circ} \mathrm{C}$, for a period of 28 days. Commercial cultures of Bifidobacterium spp. were added to milk fermented by Streptococcus thermophillus and stored for 28 days at 4 and $10^{\circ} \mathrm{C}$. During this period, bifidobacteria and S. thermophillus cultures were monitored to check their behavior in the evaluated storage conditions. Viable bifidobacteria and $S$. thermophillus counts showed no significant variation during storage at 4 and $10^{\circ} \mathrm{C}(\mathrm{p}<0.05)$, indicating that both of these conditions are adequate for maintaining their initial concentrations. The results indicate that the storage conditions usually adopted in sale establishments of dairy products are suitable to maintain bifidobacteria and S. thermophillus cultures in fermented milk.
\end{abstract}

KEYWORDS: storage; probiotic; fermented milk; bifidobacteria.

\begin{abstract}
RESUMO: As variaçóes de temperatura que ocorrem durante a cadeia refrigerada da produçáo leiteira pode interferir na qualidade de alimentos bioativos, como leites fermentados. Bactérias probióticas são usualmente adicionadas a alimentos, visando a oferecer ao consumidor efeitos benéficos. O objetivo deste trabalho foi avaliar a viabilidade de culturas probióticas de bifidobactérias e de cultura starter de Streptococcus thermophilus em leites fermentados, armazenados nas temperaturas de 4 e $10^{\circ} \mathrm{C}$ por um período de 28 dias. Culturas comerciais de Bifidobacterium spp. foram adicionadas ao leite fermentado produzido com Streptococcus thermophillus e estocados por 28 dias a 4 e $10^{\circ} \mathrm{C}$. Nesse período, as culturas de Bifidobacterium spp. e Streptococcus thermophillus foram monitoradas, com o objetivo de verificar seus comportamentos nas temperaturas de estocagem testadas. As contagens de ambos os micro-organismos não apresentaram variaçáo significativa ao longo do período de estocagem a 4 e a $10^{\circ} \mathrm{C}(\mathrm{p}<0,05)$, indicando que as duas temperaturas testadas podem oferecer condiçôes adequadas de conservação desse produto. Os resultados obtidos indicaram que as condiçóes de conservação de alimentos usualmente adotadas para produtos lácteos em estabelecimentos comerciais são adequadas para manter as contagens de bifidobactérias e Streptococcus thermophillus em leites fermentados.
\end{abstract}

PALAVRAS-CHAVE: estocagem; probiótico; leite fermentado; bifidobactéria.

\footnotetext{
'Departamento de Tecnologia de Alimentos, Centro de Ciências Exatas; Universidade Federal de Viçosa (UFV) - Viçosa (MG), Brazil. ${ }^{2}$ Departamento de Veterinária, Centro de Ciências Biológicas e da Saúde; UFV - Viçosa (MG), Brazil.

*Corresponding author: antoniofernandes@ufv.br; nero@ufv.br

Received on: 01/25/2013. Accepted on: 12/03/2014
} 
The cold storage of milk and dairy products, since the beginning of the production chain, has received great attention in several countries in the past years, including Brazil and other Latin American countries (Perin et al., 2012). In Brazil, the inclusion of this procedure in the dairy production is usually referred to as the "cold chain", and it is subjected to variations due to distinct characteristics of milk production: for raw milk, storage in dairy farms is allowed at temperatures ranging from 4 to $7^{\circ} \mathrm{C}$, when at industry arrival variations of up to $10^{\circ} \mathrm{C}$ are permitted (BRASIL, 2011). On retail sale, dairy products such as fermented milk are usually maintained at $10^{\circ} \mathrm{C}$ (BRASIL, 2000).

These variations in storage temperature can determine a deleterious result in dairy products. These conditions enable the growth of distinct spoilage and pathogenic microorganisms that are able to jeopardize the quality and safety of such products (AмMoR; MAYo, 2007). Such variation in storage temperature has a particular concern for dairy products that are considered as "live foods", such as fermented milks: the temperature variation while storing these products can affect the viability and the concentrations of the added starter and probiotic cultures (SHAH, 2000).

According to the Food and Agriculture Organization (FAO) and the World Health Organization (WHO), probiotics are live organisms that, when administered at adequate amounts, have a beneficial effect on the health of the host. Once in the host's intestinal tract, these microorganisms cause changes in the intestinal microbiota in order to modulate the immune system, inhibit the adherence and multiplication of pathogens, and also prevent obesity and some types of cancer (LourensHattingh; Viljoen, 2001). Ideally, probiotic cultures should present populations between $10^{5}$ and $10^{7} \mathrm{CFU} . \mathrm{g}^{-1}$ during the entire shelf life of the food, so that it can assure the desired beneficial effects for the consumer after ingestion (АмMOR; Mayo, 2007; Davidson et al., 2000).

The present study aimed to investigate how usual variation in the storage temperature can interfere in the populations of starter and probiotic cultures in a fermented milk, during its shelf-life.

Four commercial cultures of lyophilized Bifidobacterium spp. were used: B. animalis Bb 12 (B1, Chr. Hansen A/S, Hørsholm, Denmark), B. lactis SAB 440A (B2, Clerici-Sacco Group, Cadorago, Italy), B. lactis BI-07 (B3, Danisco A/S, Copenhagen, Denmark) and B. longum LGM P-17500 (B4, Centro Sperimentale del Latte, Zelo Buon Persico, Italy). An additional culture of $S$. thermophillus (ST 066, Clerici-Sacco Group) was used to produce fermented milk, previously added to 3 liters of milk and stored at $-18^{\circ} \mathrm{C}$ until it was ready to be used.

Pasteurized nonfat milk was heated at $90^{\circ} \mathrm{C}$ for five minutes and cooled to $39^{\circ} \mathrm{C}$, and then fermented for 4 hours by the addition of ST 066 (Clerici-Sacco Group) in a concentration of about $10^{7}$ colony forming units per $\mathrm{g}(\mathrm{CFU} / \mathrm{g})$. After fermentation, B1, B2, B3 and B4 were added in concentrations of about $10^{7} \mathrm{CFU} / \mathrm{g}$, in batches separated from the fermented milk, and distributed in sterile $200 \mathrm{~mL}$ flasks. The fermented milk samples were produced in three repetitions and stored at 4 and $10^{\circ} \mathrm{C}$ for 28 days.

Immediately after the fermented milk was bottled and at seven-day intervals, a sample of each fermented milk batch was submitted to microbiological analysis. Aliquots of the samples were submitted to ten-fold dilution using $\mathrm{NaCl} 8.5 \mathrm{~g} / \mathrm{L}$, being two dilutions selected and pour-plated in duplicate using NNLP (MRS broth [Oxoid Ltd., Basingstoke, England] added to nalidixic acid, neomycin sulfate, lithium chloride and paramomycine sulfate) (Laroia; Martin, 1991; Shah, 2000) and M17 (Oxoid) culture media. NNLP plates were incubated at $37^{\circ} \mathrm{C}$ for 48 hours under anaerobic conditions (GasPak EZ ${ }^{\mathrm{Tm}}$ Gas Generating Container Systems, BD) to enumerate the Bifidobacterium spp., and M17 plates were incubated at $37^{\circ} \mathrm{C}$ for 48 hours under aerobic conditions for $S$. thermophillus enumeration. After incubation, the colonies formed in both culture media were enumerated and the final results were expressed as $\mathrm{CFU} / \mathrm{g}$.

The obtained counts for bifidobacteria and $S$. thermophillus cultures were converted in $\log _{10}$, and compared considering different refrigeration temperatures and storage time, using the Analysis of Variance and the Tukey test $(\mathrm{p}<0.05)$ to determine significant differences. All of the analyses were performed using STATISTICA Software 7.0 (StatSoft Inc., Tulsa, OK, USA).

The mean counts obtained for the different bifidobacteria and S. thermophillus cultures in fermented milk stored at 4 and $10^{\circ} \mathrm{C}$ and in different storage periods are shown in Tables 1 and 2, respectively. No significant differences were found between the different populations observed in the assessed incubation temperatures and periods, indicating that the populations of cultures used remained stable during the study.

Considering that the initial populations of bifidobacteria cultures were about $10^{7} \mathrm{CFU} / \mathrm{g}$, typical of fermented milk with added probiotics (ZACARCHENCO; MASSAGUER-Roig, 2006), stocking at $4^{\circ} \mathrm{C}$ allowed the concentration to be adequately preserved, and the same was true for the $10^{\circ} \mathrm{C}$ temperature (Table 1). This temperature variation $\left(4\right.$ to $\left.10^{\circ} \mathrm{C}\right)$ is usually observed in sale establishments, and, depending on the cultures that are present in different foods, it may lead to significant multiplication. Moreover, the $4^{\circ} \mathrm{C}$ temperature is usually recommended to maintain microbial populations in milk and milk products to prevent their deterioration (Robinson, 2002). Nevertheless, Brazilian legislation allows fermented milk to be preserved at temperatures of $10^{\circ} \mathrm{C}$ in sale establishments (BrASIL, 2000). In a similar study, no significant changes were observed in the populations or in the culture viability of bifidobacteria added to yogurt (VINDEROLA et al., 2002) produced with different types of additives. In another study (CRUZ et al., 2010), it was possible to observe that a commercial yogurt kept the count of bifidobacteria at 7 to $8 \log$ for 84 days at $10^{\circ} \mathrm{C}$.

In relation to $S$. thermophillus, some types of fermented milk with specific added cultures of bifidobacteria ranged during different storage periods and temperatures, but at no significant level (Table 2). Oliveira et al. (2002) described a similar behavior for $S$. thermophillus cultures in fermented 
Table 1. Mean counts of bifidobacteria cultures from fermented milk (prepared with Streptococcus thermophilus) stored at 4 and $10^{\circ} \mathrm{C}$ for 28 days, obtained by NNLP culture media by conventional plating.

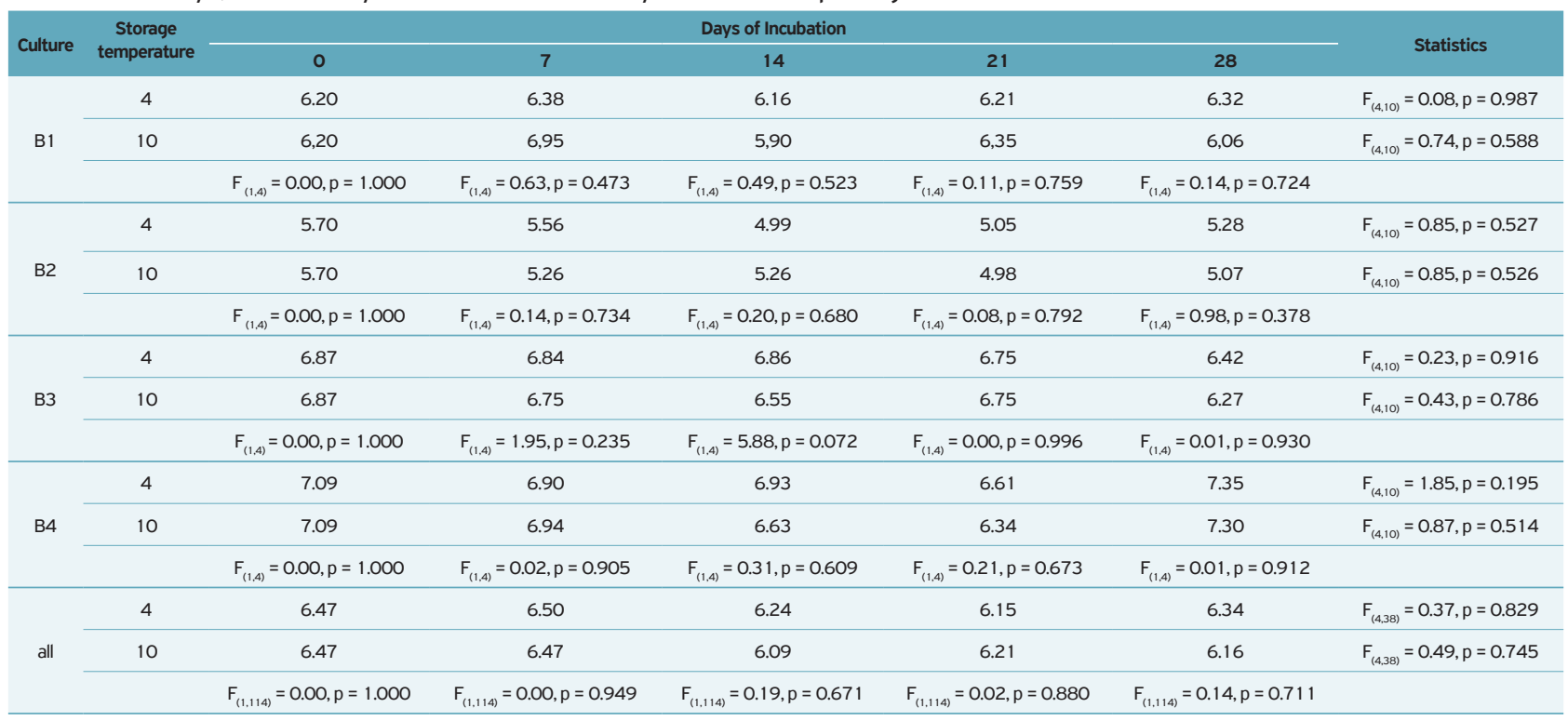

*All statistics presented: Analysis of Variance (ANOVA). Mean counts with distinct lower case indicate significant differences in a same row (Tukey test, $\mathrm{p}<0.05$ ). Mean counts with distinct upper case indicate significant differences in the same column (Tukey test, $\mathrm{p}<0.05$ ); nc $=$ no counts recorded; $\mathrm{F}=$ ANOVA test; $\mathrm{df}=$ degrees of freedom; $\mathrm{p}=$ level of significance.

Table 2. Mean counts of Streptococcus thermophilus from fermented milk (added to bifidobacteria cultures) stored at 4 and $10^{\circ} \mathrm{C}$ for 28 days, obtained by $\mathrm{M} 17$ culture media by conventional plating.

\begin{tabular}{|c|c|c|c|c|c|c|c|}
\hline \multirow{2}{*}{$\begin{array}{c}\text { Added } \\
\text { bifidobacteria }\end{array}$} & \multirow{2}{*}{$\begin{array}{l}\text { Storage } \\
\text { temperature }\end{array}$} & \multicolumn{5}{|c|}{ Days of Incubation } & \multirow{2}{*}{ Statistics } \\
\hline & & 0 & 7 & 14 & 21 & 28 & \\
\hline \multirow{3}{*}{ B1 } & 4 & 7.85 & 8.88 & 7.71 & 8.47 & 7.80 & $F(4,10)=0.36, p=0.831$ \\
\hline & 10 & 7.85 & 9.03 & 8.92 & 8.42 & 7.90 & $F(4,10)=1.36, p=0.320$ \\
\hline & & $F(1,4)=0.00, p=1.000$ & $F(1,4)=0.02, p=0.889$ & $F(1,4)=0.79, p=0.425$ & $F(1,4)=0.01, p=0.926$ & $F(1,4)=0.02, p=0.889$ & \\
\hline \multirow{3}{*}{ B2 } & 4 & 8.50 & 8.57 & 8.88 & 8.43 & 8.32 & $F(4,10)=0.19, p=0.940$ \\
\hline & 10 & 8.50 & 8.55 & 8.85 & 9.16 & 8.62 & $F(4,10)=0.52, p=0.725$ \\
\hline & & $F(1,4)=0.00, p=1.000$ & $F(1,4)=0.09, p=0.745$ & $F(1,4)=0.01, p=0.937$ & $F(1,4)=1.10, p=0.353$ & $F(1,4)=0.23, p=0.657$ & \\
\hline \multirow{3}{*}{ B3 } & 4 & 7.86 & 8.34 & 8.48 & 6.27 & 8.14 & $F(4,10)=1.42, p=0.298$ \\
\hline & 10 & 7.86 & 8.72 & 7.65 & 7.08 & 7.72 & $F(4,10)=0.79, p=0.558$ \\
\hline & & $F(1,4)=0.00, p=1.000$ & $F(1,4)=0.10, p=0.768$ & $F(1,4)=2.46, p=0.192$ & $F(1,4)=3.20, p=0.148$ & $F(1,4)=0.06, p=0.816$ & \\
\hline \multirow{3}{*}{ B4 } & 4 & 8.14 & 8.25 & 8.24 & 7.38 & 7.90 & $F(4,10)=0.26, p=0.896$ \\
\hline & 10 & 8.14 & 8.32 & 8.43 & 7.18 & 8.75 & $F(4,10)=0.89, p=0.507$ \\
\hline & & $F(1,4)=0.00, p=1.000$ & $F(1,4)=0.00, p=0.952$ & $F(1,4)=0.18, p=0.692$ & $F(1,4)=0.05, p=0.834$ & $F(1,4)=0.35, p=0.594$ & \\
\hline \multirow{3}{*}{ all } & 4 & 8.07 & 8.51 & 8.33 & 7.64 & 8.06 & $F(4,38)=0.99, p=0.424$ \\
\hline & 10 & 8.07 & 8.65 & 8.47 & 7.96 & 8.20 & $F(4,38)=1.04, p=0.395$ \\
\hline & & $F(1,114)=0.00, p=1.000$ & $F(1,114)=0.10, p=0.758$ & $F(1,114)=0.12, p=0.729$ & $F(1,114)=0.46, p=0.502$ & $F(1,114)=0.07, p=0.790$ & \\
\hline
\end{tabular}

*All statistics presented: Analysis of Variance (ANOVA). Mean counts with distinct lower case indicate significant differences in a same row (Tukey test, $p<0.05$ ). Mean counts with distinct upper case indicate significant differences in a same column (Tukey test, $p<0.05$ ); nc $=$ no counts recorded; $F=$ ANOVA test; $\mathrm{df}=$ degrees of freedom; $p=$ level of significance.

dairy products containing probiotic cultures, whereas significant interferences were observed only in products fermented by Lactobacillus after storage at $4^{\circ} \mathrm{C}$ for 21 days.

The viability of bifidobacteria cultures in fermented products during storage may be influenced by certain factors, such as post-acidification, oxygen content and presence of antimicrobial compounds (SнAн, 2001). Considering that only the $S$. thermophillus culture was used for fermentation, and that its population remained stable during the entire storage period and at the different temperatures under assay (Table 2), acidity was most likely controlled, therefore, it did not interfere with the viability of the added probiotic culture (Table 1). By using a type of cheese with $S$. thermophilus as starter culture to deliver probiotic strains, BERGAMINI et al. (2010) 
showed that the $B$. lactis population maintained more than $10^{7} \mathrm{CFU} \cdot \mathrm{g}^{-1}$ throughout the 60 days of ripening at $12^{\circ} \mathrm{C}$, even if with some statistical difference.

The results obtained lead to the conclusion that the storage conditions assessed, usually observed in dairy industries and sale establishments, allowed the adequate preservation of populations of commercial bifidobacteria cultures added to fermented milk produced with $S$. thermophillus.

\section{ACKNOWLEDGMENTS}

Luís A. Nero and Antônio F. Carvalho are supported by CNPq and FAPEMIG. Rodrigo O. Miranda, Gabriel Gama Netto, and Rosângela Freitas are supported by CAPES. The authors also thank Chr. Hansen A/S, Clerici-Sacco Group, Danisco $\mathrm{A} / \mathrm{S}$, and Centro Sperimentale del Latte, for providing the bifidobacteria and the $S$. thermophilus commercial cultures.

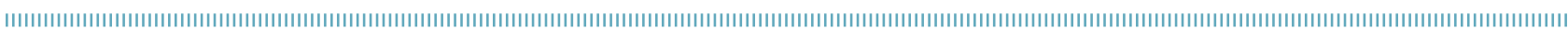

\section{REFERENCES}

AMMOR, M.S.; MAYO, B. Selection criteria for lactic acid bacteria to be used as functional starter cultures in dry sausage production: An update. Meat Science, v.76, p.138-146, 2007.

BERGAMINI, C.; HYNES, E.; MEINARDI, C.; SUÁREZ, V.; QUIBERONI, A.; ZALAZAR, C. Pategrás cheese as a suitable carrier for six probiotic cultures. Journal of Dairy Research, v.77, p.265-272. 2010.

BRASIL. Ministério da Agricultura, Pecuária e Abastecimento. Resolução № 5: Regulamento técnico de identidade e qualidade de leites fermentados. Brasília: MAPA, 2000.

BRASIL. Ministério da Agricultura, Pecuária e Abastecimento. Instrução Normativa n 62. Regulamento Técnico de Produção, Identidade e Qualidade do Leite tipo A, o Regulamento Técnico de Identidade e Qualidade de Leite Cru Refrigerado, o Regulamento Técnico de Identidade e Qualidade de Leite Pasteurizado e o Regulamento Técnico da Coleta de Leite Cru Refrigerado e seu Transporte a Granel. Brasília: MAPA, 2011.

CRUZ, A.G.; WALTER, E.H.M.; CADENA, R.S.; FARIA, J.A.F.; BOLINI, H.M.A.; PINHEIRO, H.P.; SANT'ANA, A.S. Survival analysis methodology to predict the shelf-life of probiotic flavored yogurt. Food Research International, v.43, p. 1444-1448, 2010.

DAVIDSON, R.H.; DUNCAN, S.E.; HACKNEY, C.R.; EIGEL, W.N.; BOLING, J.W. Probiotic culture survival and implications in fermented frozen yogurt characteristics. Journal of Dairy Science, v.83, p.666-673, 2000.

LAROIA, S.; MARTIN, J.H. Methods for enumerating and propagating bifidobacteria. Cultured Dairy Products Journal, v.26, p.32-33, 1991.
LOURENS-HATTINGH, A.; VILJOEN, B.C. Yogurt as probiotic carrier food. International Dairy Journal, v. 11, p.1-17, 2001.

OLIVEIRA, M.N.; SODINI, I.; REMEUF, R.; TISSIER, J.P.; CORRIEU, G. Manufacture of fermented lactic beverages containing probiotic cultures. Journal of Food Science, v.67, p.23362341, 2002.

PERIN, L.M.; MORAES, P.M.; ALMEIDA, M.V.; NERO, L.A. Interference of storage temperatures in the development of mesophilic, psychrotrophic, lipolytic and proteolytic microbiota of raw milk. Semina: Ciências Agrárias, v.33, p.333-342, 2012.

ROBINSON, R.K. Dairy Microbiology Handbook: The microbiology of milk and milk products. $3^{\text {rd }}$ ed. New York: Wiley-Interscience, 2002.

SHAH, N.P. Probiotic Bacteria: Selective enumeration and survival in dairy foods. Journal of Dairy Science, v.83, p.894-907, 2000.

SHAH, N.P. Functional foods from probiotics and prebiotics. Food Technology, v.55, p.46-52, 2001.

VINDEROLA, C.G.; COSTA, G.A.; REGENHARDT, S.; REINHEIMER, J.A. Influence of compounds associated with fermented dairy products on the growth of lactic acid starter and probiotic bacteria. International Dairy Journal, v. 12, p.579-589, 2002.

ZACARCHENCO, P.B.; MASSAGUER-ROIG, S. Properties of Streptococcus thermophilus fermented milk containing variable concentrations of Bifidobacterium longum and Lactobacillus acidophilus. Brazilian Journal of Microbiology, v.37, p.338344, 2006. 